\title{
面材を釷打ちした耐力壁のせん断剛性および 強度に関する理論的研究
}

正会員神谷文 夫*

\section{1 序}

合板や石亮ボード等の面材料を，壁枠に釷打ちして構 成した耐力壁は, 枠組壁工法をはじめとするパネル工法 の基幹をなすものであるが，そのせん断機構は十分に解 明されて拈らず，その性能評価に際しては，主として実 大規模の壁試験による方法が採られてきた。

しかしながら，こうした試験は大きな装置と多くの経 費を要するために，量的制約を受け，その試験範囲は広 範な材料や設計，さらには環境等の条件を網羅するには 至っていない。

これに対して, 壁のせん断性能にとって最も重要なパ ラメータであると考えられる，面材料と枠材の釷接合部 については, 試験体も小型であるために, 比重や含水率 等の種々の影響因子を考慮した研究をはじめ, 長期荷重 や繰り返し荷重を受けた場合等の広範な研究が行われて いる。

釷接合部の特性等から而力壁のせん断性能を計算する 理論が誘導できれば, 釘接合部に関するこれ等の研究成 果を活用して，各種因子の影響を含めたより詳細な壁の せん断性能が，実大規模の壁試験を行わずして求められ るだけでなく，長期的な性能予測も可能になるものと思 われる。

本研究はこのような目的の下に, 耐力壁のせん断剛性 と最大耐力を予測する理論式の誘導を試みるとともに， その適合性について実験的に検討を加えたものである。

\section{2 既往の研究}

これまでの研究は，その手法によって 3 種類に大別さ れる。すなおち，(1) 実験式を求めたもの 要素法により計算したもの ${ }^{4}$, (3) 理諭式を誘導したも の) 8)である。このうち, (1) は有効範囲が狭く, (2) は 正確な解を得る可能性のある反面，電算機の容量に精度 が限定され，またパラメータの影響について值截に知る ことができない不便さがある。(3)の中では, R.L. Tuo$\mathrm{mi}$ 等のものが代表的である。この研究注釗接合部の特 性を直線であるとみなして最大耐力を計算したものであ るが，せん断剛性を予測し得るものではない。

\section{3 理論式の誘導}

\footnotetext{
* 農林水産省林業試験場 研究員

（昭和 56 年 3 月 20 日本稿受理・討論期限昭和 57 年 2 月末日）
}

耐力壁のせん断歪み $r$ は, 面材のせん断歪夕 $r_{S}$ と, 面材一枠材間の之りによって生じるせん断歪み $\gamma_{N}$ とが 合成されたものであると考える。すなわち，

$$
r=r_{S}+r_{N}
$$

3.1 面材のせん断歪み $r_{s}$

面材内のせん断応力の分布は一様ではないが，ここで は簡単に次式で表わされるものと考える。

$$
r_{S}=\frac{P}{l t G}
$$

但し， $P$ 注水平力, $l$ は面材の有効な幅（コーナ一釷 間の水平距離， $t$ 注面材の厚さ， $G$ 注面材のせん断弹性 係数である。

\section{2 面材一枠材間の之りによるせん断歪み $r_{N}$} 計算に先立って，次のような仮定を設けた。

イ、染材相互の接合部はピンであるとする。

口. 枠材には, 曲げ, 引張, 圧縮, せん断等の変形が 生じないものとする。

八. 枠組, および釷打ちのパターンは, 壁の上下, 左 右に対して対称である。

いま，釷接合部の釘 1 本に対するせん断力 $q$ と変位量 $\delta$ との関係を，異方性を無視して次のように表す。

$$
q=f(\delta)
$$

計算対象の例として，上下枠と等間隔に配置された 3 本 の縦枠からなる枠組みに 1 枚の面材を張った耐力壁を考 える。コーナ釷の変位 $\delta_{c}$ (以下, 釘接合部に括ける之り

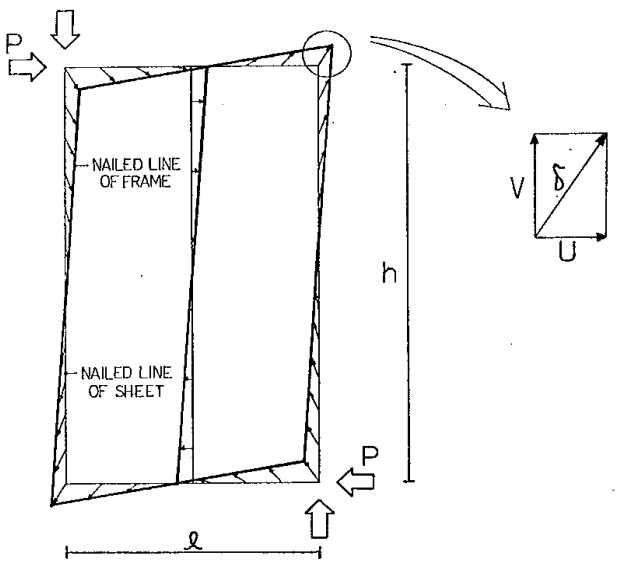

Fig. 1 Directions and relative magnitude of nail displacement 
を釷の変位と記す) の $x$ (水平) 方向, $y$ （垂直）方向成分を $u$, vとすると，他の釷の変位成分 は，仮定(イ)〜(八)办ら幾何学 的に求められる (Fig. 1 参照)。 釘の位置をサフィックス $i, j, k$ 等で示すと (Fig. 2 参照),

$$
\begin{aligned}
& u_{i}=u, u_{j}=\frac{Y+1-2 j}{Y-1} u, \\
& u_{k}=\frac{Z+1-2 k}{Z} u \\
& v_{i}=\frac{X+1-2 i}{X-1} v, \quad v_{j}=v, \\
& v_{k}=0
\end{aligned}
$$

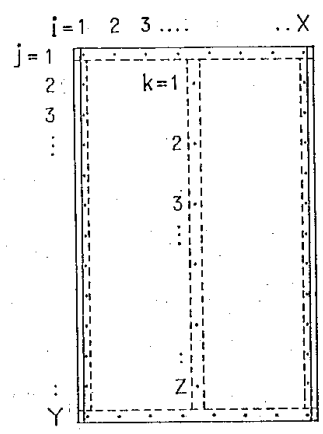

Fig 2 Numbering of nail

但し, $X, Y, Z$ 注各枠材 $の$ 釷本数。

したがって各釷の変位 $\delta$, せん断力の成分 ${ }_{x} q, y q$ は，

$$
\left.\begin{array}{l}
\delta_{i, j, k}=\sqrt{u_{i, j, k}{ }^{2}+v_{i, j, k}{ }^{2}} \ldots . \\
{ }_{x} q_{i, j, k}=\frac{u_{i, j, k}}{\delta_{i, j, k}} f\left(\delta_{i, j, k}\right) \\
y q_{i, j, k}=\frac{v_{i, j, k}}{\delta_{i, j, k}} f\left(\delta_{i, j, k}\right)
\end{array}\right\}
$$

となる。但し，式 (5)，(6) は，同じサフィックスにつ いて読む。

各釘のせん断力による面材の中心のまわりの回転モー メントに注目すると， $x q$ は右回り, $y q$ は左回りのモー メントを与える。その総和を ${ }_{x} M,{ }_{y} M$ とすると，

$$
\begin{aligned}
& { }_{x} M=2 \sum_{i=1}^{X}\left({ }_{x} q_{i} \frac{h}{2}\right)+2 \sum_{j=2}^{X-1}\left({ }_{x} q_{j}\left|\frac{Y+1-2 j}{Y-1}\right| \frac{l}{2}\right) \\
& +\sum_{k=1}^{Z}\left({ }_{x} q_{k}\left|\frac{Z+1-2 k}{Z}\right| \frac{h}{2}\right) \\
& { }_{y} M=-\left\{2 \sum_{i=1}^{X}\left({ }_{y} q_{i}\left|\frac{X+1-2 i}{X-1}\right| \frac{h}{2}\right)\right. \\
& \left.+2 \sum_{j=2}^{Y-1}\left(y q j \frac{l}{2}\right)\right\}
\end{aligned}
$$

但し，hはコーナ釘間の鉛直距離である。

式 (3)〜(7) では $\Sigma$ を用いたが,「枠材の単位長さ当り の釘せん断力 $q / s 」(s$ は釗間隔) を考えて，これ吕枠 材に沿って連続的に分布していると仮定すれば，式 (7)，

（8）は積分の形で書くことができ，次のようになる。

$$
\begin{aligned}
{ }_{x} M= & \frac{u l h}{v s_{x}} \int_{u}^{\delta_{c}} \frac{f(t)}{\sqrt{t^{2}-u^{2}}} d t+\frac{h^{2}}{u^{2} s_{y}} \int_{v}^{\delta_{c}} \sqrt{t^{2}-v^{2}} f(t) d t . \\
& +\frac{h^{2}}{2 u^{2} s_{z}} \int_{v}^{\delta_{c}} \sqrt{t^{2}-v^{2}} f(t) d t \ldots \ldots \ldots \ldots \ldots \ldots(7)^{\prime} \\
y= & -\left\{\frac{l^{2}}{v^{2} s_{x}} \int_{u}^{\delta_{c}} \sqrt{t^{2}-u^{2}} f(t) d t\right. \\
& \left.+\frac{v l h}{u s_{y}} \int_{u}^{\delta_{c}} \frac{f(t)}{\sqrt{t^{2}-v^{2}}} d t\right\} \ldots \ldots \ldots \ldots \ldots \ldots \ldots(8)
\end{aligned}
$$

式 $(7)^{\prime},(8)^{\prime}$ は，釷の $q=f(\delta)$ 曲線をうをく適合する 式で表す事ができれば机上の計算が可能であることを示 している。更に釘間隔 $s$ が積分記号の外に出ているの で，後の式 (9)，(11)'等とから釬間隔が壁のせん断性 能に与える影響を推察することができる。
以上は釘間隔が各枠材每で等しい場合の式であるが， 等しくない場合です仮定（ハ）を満足すれば，式 (3)〜 （7）と同じ方法で ${ }_{x} M,{ }_{y} M$ を求めることができる。 回転モーメントの釣り合いから次式が成立する

$$
{ }_{x} M+{ }_{y} M=0
$$

式 (7)，(8)，(9) 又は式 (7)'，(8)'，(9) を解けば，u と $v$ の関係（コーナ釷の変方向）が得られる。計算を行ら にあたって， $q=f(\delta)$ の関係を与じめ実験等から求める 必要がある。本研究では，得られた釘の実験データを， 多数の直線（15３0 本）加らなる折線にみたて，式 (7)， （8）を用いて数值計算（ $u$ とvの值の一方を固定し他方 を変えて，式 (9) を満足する $u$ とvの組み合せをで きるだけ多く求める)で解いた。計算によると，コーナ 釷の変形方向は $q=f(\delta)$ 曲線の形によって異なり, ま た変形が進むにつれて方向む変化するので，この方向が 面材の対角方向であるとする Tuomi 等の仮定とは, 必 ずしも一致しない。

$u, v$ と $r_{N}$ との関係は,

$$
r_{N}=\frac{2 u}{h}+\frac{2 v}{l} \text {. }
$$

また，外力のなす仕事量と，各釷のなす仕事量の総和と は等しいから，

$$
\begin{aligned}
& \int_{0}^{r_{N}} P h r d r=2 \sum_{i=1}^{X}\left(\int_{0}^{\delta_{i}} f(\delta) \delta d \delta\right) \\
& \quad+2 \sum_{j=2}^{X-1}\left(\int_{0}^{\delta_{j}} f(\delta) \delta d \delta\right)+\sum_{k=1}^{Z}\left(\int_{0}^{\delta_{k}} f(\delta) \delta d \delta\right)
\end{aligned}
$$

これより最終的に $P-\delta_{N}$ の関倸が求められる。な扣式 (11) は次式と同じ結果を与えるので，計算は簡単にな る。

$$
P=\frac{x M}{h}
$$

マルチスタッドの場合：式 (4)〜 (6) にならってスタ ッドの釷の変位, せ九断力を計算し, 回転モーメントを 式 (7)，(8) に加えればよい。

2 枚以上の面材を張った場合：まず 1 枚の面材を張っ た部分每に $P-r$ の関係を求める。縦張りの場合は面材 寸法が異なっても， $r_{N}$ 注等しいとの条件の下でせん断 力を加算する。横張りで面材寸法が等しい場合は 1 枚の 面材を張った部分についての計算が解となる。横張りで 面材寸法が異なる場合は次のどちらかで近似的に解を得 る。(1) 縦染の面内方向の曲げ用性が低いとき $(2 \times 4$ 工 法の場合等）は，面材の継ぎ目の位置で縦枠はピンにな っていると仮定して，同じ $P$ に対するせん断歪みを合 成する（縦染は屈曲点を持つ。この現象は実験でしばし ば観察される)。(2) 縦伜剛性が高いときは，せん断歪み は上下の各部分で等しいと仮定して, 次式でせん断力を 合成する。すなわち, $P=\left(P_{1} h_{1}+P_{2} h_{2}\right) /\left(h_{1}+h_{2}\right)$, 但し $P_{1}, P_{2}$ 注高さ方向の寸法 $h_{1}, h_{2}$ の各部分について計 算した同じ $r$ に対するせん断力である。 


\section{3 近似式}

いま, $q-\hat{o}$ の関係が直線であると仮定し $, q=\propto \delta, \propto$ は 定数，とすると式 (4)〜 (11) は机上で解け,

但し，

$$
P=\frac{B l}{h} \alpha v, v=\frac{(A+C) h^{2} l}{2\left\{(A+C) h^{2}+B l^{2}\right\}} r_{N} \cdots
$$

$$
\begin{aligned}
& A=X+\frac{(Y-2)(Y-3)}{3(Y-1)}, B=Y+\frac{(X-2)(X-3)}{3(X-1)} \\
& C=\frac{(Z+1) \cdot(Z-1)}{6 Z}
\end{aligned}
$$

となる。近似式の適用範囲を，寸法比 2 3 の面材を縦 張りし，釷間隔を面材の外周で等しくした壁に限定寸れ ば，各釗変位の最大值法 $\delta_{c}$ (コーナ), 最小值は $u$ (上下枠中央) で, $v$ (縦 枠中央) はこれ等の中間 的な值となる。式 (12): に扔いて, $\alpha v=f(v)$ と すると、これは Fig. 3 に示すように, 直線 $q=$ $\alpha \delta$ を区間 $u \leqq \delta \leqq \delta_{c}$ で 曲線 $q=f(\delta)$ 次置換し たことになり，式 (11) は次のように書き換えら

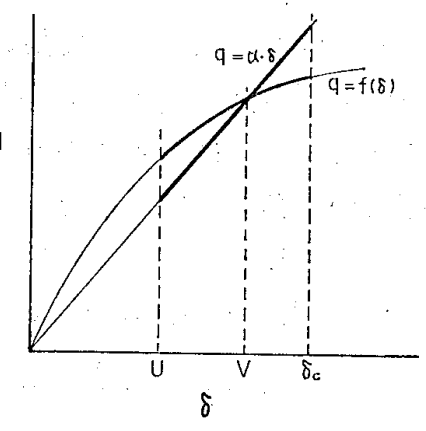

Fig. $3 q=\alpha \delta$ is approximated by $q=f(\delta)$ in the interval $u \leqq \delta \leqq \delta_{c}$ れる。

$$
P=K_{1} f\left(\frac{r_{N}}{K_{2}}\right)
$$

但し,

$$
K_{1}=B \frac{l}{h}, \quad K_{2}=\frac{2\left\{(A+C) h^{2}+B l^{2}\right\}}{(A+C) h^{2} l}
$$

この式が近似式である。近似解の求め方は，まず $K_{1}$, $K_{2}$ を計算し，実験で得られた釘の $q-\delta$ グラフの各軸ス ケールに $K_{1}, K_{2}$ を乗ずれば良い。スケール変更された グラフがそのまま壁の $P-r_{N}$ 曲線になる。これれ面材 のせん断歪み $r_{S}$ を計算して加えれば， $P-r$ 曲線が得ら れる。な㧍グラフの有効範囲は

$$
r_{N} \leqq K_{2} \sqrt{\left(\frac{K_{1}}{A+C}\right)^{2}+1} \delta_{\max }
$$

但し， $\delta_{\max }$ 注釷耐力最大時のスリップ

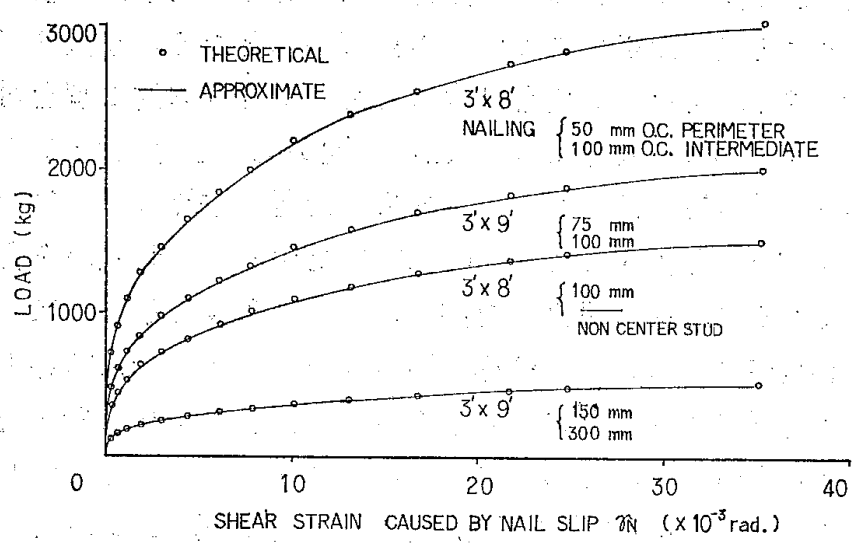

Fig. 4 Validity of the approximate formula
各種面材の $q-\delta$ の関係を用いて, 理論解と近似解の比 較を行ったが，Fig. 4 に例を示すよらに，雨者は非常 に良く一致し，近似式は高い精度を有する事が判った。

\section{4 実 験}

\section{1 試験体および試験方法}

試験体の寸法は，いずれも $1820 \times 2400 \mathrm{~mm}$ とした。 面材の種類は，そのせん断剛性执よび位接合性能を考虑 して選択した。構造用合板張りの場合は，張り方を違え て検討した。また，合板を接着（レゾルシ)ール樹脂， 釘圧締) した壁についても検討した（Table 1，Fig: 5 参照)。

枠材には，断面 $40 \times 90 \mathrm{~mm}$ のベイツガ（含水率 12 15\%）を用い，釘接合部に招ける摩擦抵抗をできるだけ 一定にするために，プレーナ仕上げを施した。なお，面 材と枠材は，同一試験体内で，その比重と曲げヤング係 数がマッチングするよう配慮した。

ラッキング試験汪，Fig. 6 に示すように，タイロッ ド方式を採用した。試験体の固定には釘（8-CN 90）を 用いたが，面外座屈を防止するために羽子板ボル卜（加 力側に 1 本）女併せて用いた。

変形は，壁全体のせん断歪み（縦染の回転から壁脚部 の回転を美し引いて求める,, に相当)，面材のせ儿断歪 み（対角方向の伸び縮みから求める， $r_{S}$ に相当），打上 び面材一枠材間の之り（測定点のズレを補正して $u, v$ を求める）を測定した。

試験終了後, 枠材飞面材の一部切り取り, LW 改良 法により，計算の入力データとなる面材のせん断弹性係 数を，また，Fig. 7 亿示す方法で釷接合部のせん断特 性を測定した。

\section{2 実験結果扔よび考察}

\section{2 .1 面材のせん断歪多 $r_{S}$}

Fig. 8 注 $P-r_{s}$ の関係を示したものである。この関 係は No. 3. を除いてほほ值線である。No. 3 法折線と なるが，これは 4 枚の合板の隅が接触するからであると 思われる。

壁ラッキング試験と面材のせん断剛性試験から求めた せん断弾性係数を Table 2 に示した (No. 3 \&荷重の 高い方の直線部分から求めた)。両者を比較すると：一 部の試験体で值の開きが大きいものもあるが，お打むね 両者は一致して打り，面材の接合法が接着，釗着の如何 にかかわらず，式 (2) が適用可能であることを示唆して いる。

\section{2 .2 面材一枠材間の之り $u ; v$}

Fig. 9 は, 理論值と赛験值との適合性が非較的良か った No.2 (合板横張り) と, 比較的悪かった No. 7 (石 衰ボード縦張り）を代表例として示したものである。

荷重一定時の $u$ と $v$ について, 理論值と実験值とを 比較すると，一般に実験值が理論值を上回り，特にuに 
Table 1 Test specimens

\begin{tabular}{|c|c|c|c|c|c|}
\hline \multirow{2}{*}{$\begin{array}{c}\text { SPECIMENS } \\
\text { NO. }\end{array}$} & & \multicolumn{3}{|c|}{ NATL } \\
\hline & MATERIALS & THICK. (mm) & TYPE & $\frac{\text { SPA }}{\frac{\text { PERIMETER }}{2}}$ & $\begin{array}{l}\text { CING }(\mathrm{mm}) \\
\text { INTEERMEDIATE }\end{array}$ \\
\hline 1 & PLYWOOD & 7.5 & CN50 & 100 & 200 \\
\hline 2 & PLYWOOD & 7.5 & CN50 & 100 & 200 \\
\hline 3 & PLYWOOD & 7.5 & CN50 & 100 & 200 \\
\hline 4 & PLYWOOD & 7.5 & CN50 & 150 & 200 \\
\hline 5 & GYPSUM BOARD & 12.0 & GN40 & 100 & 200 \\
\hline 6 & INSULATION BOARD & 12.0 & SN 40 & 100 & 200 \\
\hline 7 & SEMI-HARD BOARD & 12.0 & CN50 & 100 & 200 \\
\hline 8 & PLYWOOD & 7.5 & & (NAILED GLU & [NG) \\
\hline
\end{tabular}

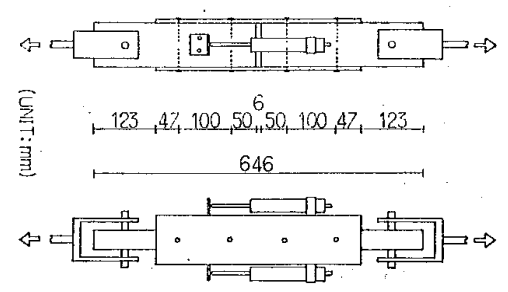

Fig. 7 Nailed joint test

理論值と実験值とが比較的一致した が、このことは，この説明にそうも

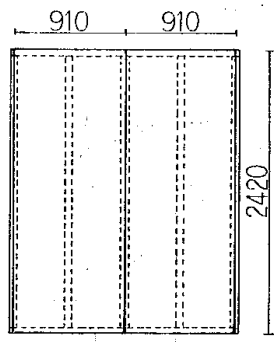

No.1, 4in 8

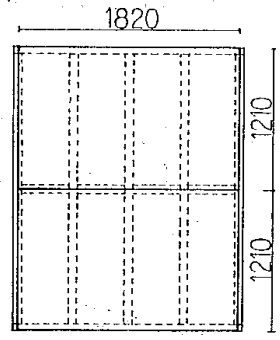

No. 2

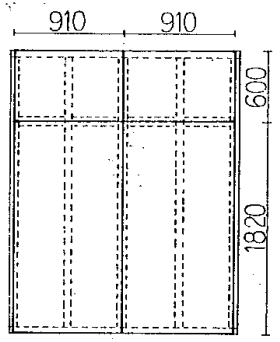

No.3
Fig. 5 Application of sheathings and framing

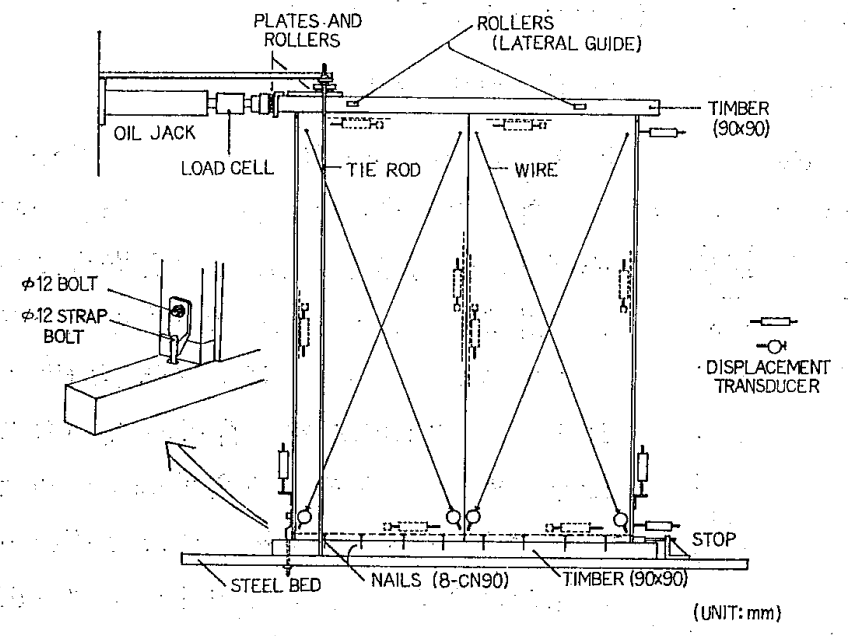

Fig. 6 Wall racking test

ついてはその程度がいちぢるしい。

いのこの傾向について原因を考えると，仮定（口）に 反し，枠材が釷より偶力を受けて曲げ変形を生じたこと があげられる (Fig. 10 参照)。この変形の度合は, 上下 枠よりも長い綐枠の方が大きかった。縦枠がこのように 曲げ変形を生じると, 縦枠の釷の $x$ 方向変位 成分は理論值よりも小さくなり，乙たがって 釷せん断力の $x$ 方向成分む小さくなる。この 結果, ${ }_{x} M$ は隇少子るので，釣り合いの式 (8), ${ }_{x} M+{ }_{y} M=0$. を満足するためには， $u$ は理論值よりも大きくならなければならな w。

縦枠のスパンが半分となる No. 2 や，釘 せん断力の低いNo. 5 あるいはNo. 6 では,
のであると考えられる。

\section{2 .3 壁全体のせん断歪み $\gamma$ 抢よび最大荷重}

Fig. 11 は P-rの関係䒚示したものであるが，rにつ いては，理論值と実験值とは打执むね一致している。最 大荷重についてむ，両者はほとんど一致しているが，理 論值の方がやや高い值を示している。これは，釘接合部 の特性を求める実験で，端距離を考慮しなかった事が一 因になっていると考えられる。

なお，計算によると，コーナ釘のせん断力が最大倠に 達し，徐々に低下を始めても，他の釘のせん断力の堌加 分がこれをカバーするので，壁の耐力はまだ幾分かの上 昇をするよらである。

枠組壁工法の耐力壁の許容耐力算定で注，せん断歪み が 1/300 rad. 時の荷重と, 最大耐力とを基準にしてい るので，これ等に関する值を Table 3 に示した。 $r=$ $1 / 300 \mathrm{rad}$. 時に面材自体のせん断歪み $r_{S}$ の占める割合

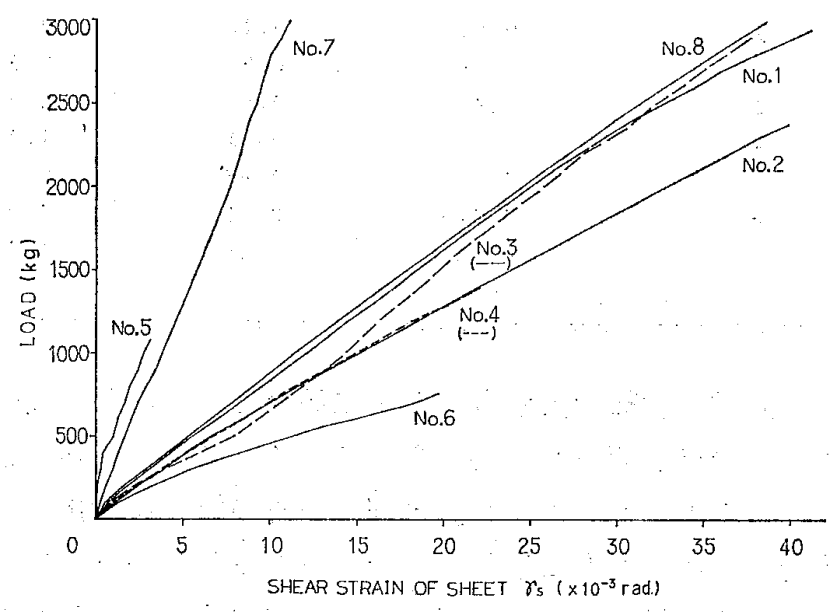

Fig. 8 Relationship between load and $\gamma_{S}$

Table 2 Comparison of $G$ which were obtained from two tests

\begin{tabular}{|c|c|c|c|}
\hline $\begin{array}{l}\text { SPECIMENS } \\
\text { NO. }\end{array}$ & $\frac{\text { MODULUS OF RIC }}{\text { PANEL TEST (1) }}$ & $\frac{T Y\left(\mathrm{kgf} / \mathrm{cm}^{2}\right)}{\text { WALL TEST (2) }}$ & RATIO $\frac{(2)}{(1)}$ \\
\hline I & 5120 & 5690 & 1.11 \\
\hline 2 & 4410 & 4390 & 1.00 \\
\hline 3 & 5120 & 5910 & 1.15 \\
\hline 4 & 4550 & 4930 & 1.08 \\
\hline 5 & 6850 & 12880 & 1.88 \\
\hline 6 & 2640 & 1170 & 0.44 \\
\hline 7 & $9390^{\circ}$ & 12240 & 1.30 \\
\hline 8 & 4510 & 4510 & 1.00 \\
\hline
\end{tabular}




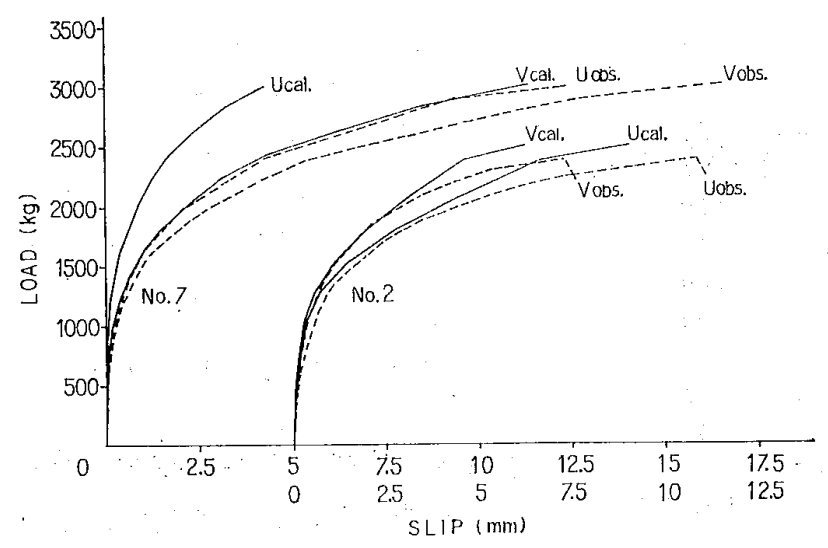

Fig. 9 Relationship between load and slip components

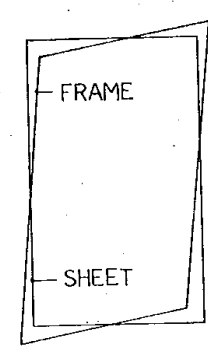

ASSUMPTIVE DEFORMATION
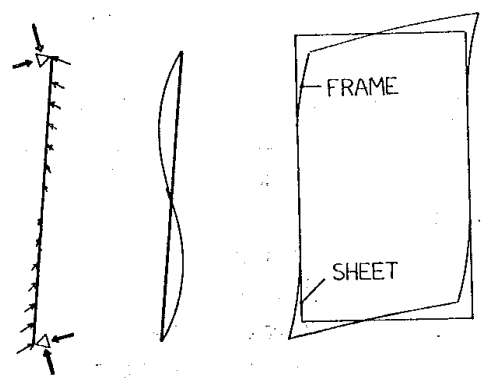

FORCES: BEENDING ACTED MOMENT UPON STUD. OF STUD

\section{OBSERVED DEFORMATION OF STUD}

Fig. 10 Deformation of stud

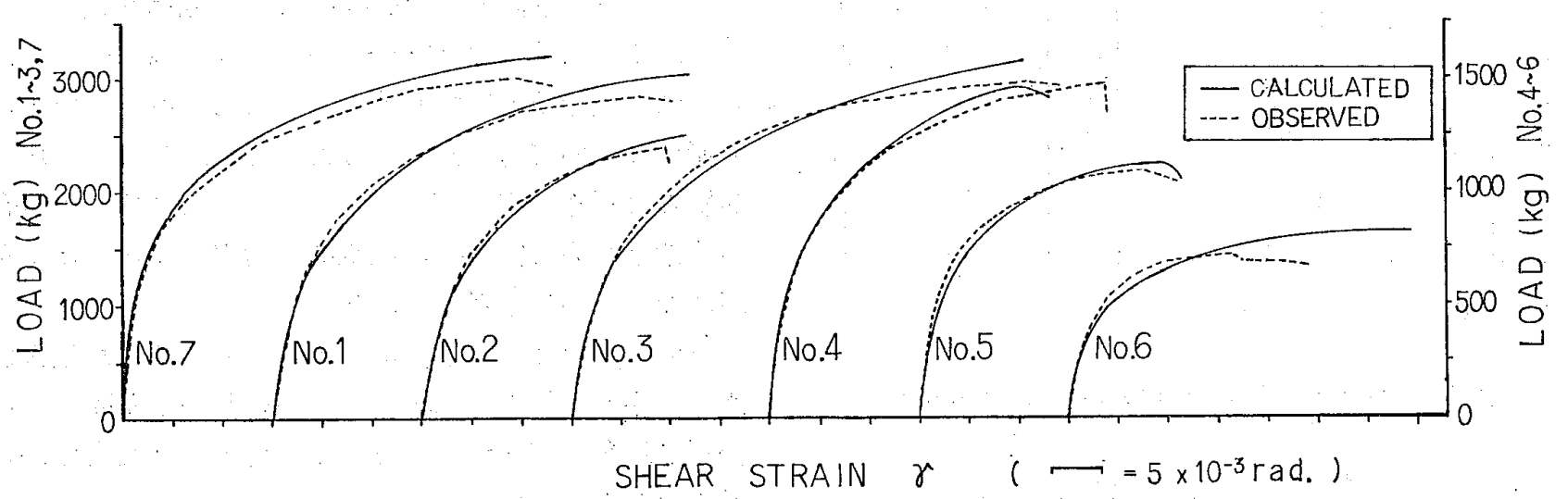

Fig. 11 Comparison of the calculated results with the experimental results

Table 3 Shear strain and load at $\gamma=1 / 300 \mathrm{rad}$. and max. load

\begin{tabular}{|c|c|c|c|c|}
\hline \multirow[b]{2}{*}{$\begin{array}{c}\text { SPECIMEN } \\
\text { NO. }\end{array}$} & \multicolumn{3}{|c|}{ AT $\gamma=1 / 300 \mathrm{rad}}$. & \multirow{2}{*}{$\frac{\text { MAX. LOAD }}{\frac{\text { PCal. }}{\text { Pobs. }}}$} \\
\hline & $\frac{\gamma \mathrm{scal}}{\gamma}$ & $\frac{\gamma s \text { obs }}{\gamma}$ & $\frac{\text { Pcal. }}{\text { Pobs. }}$ & \\
\hline$I$ & 0.52 & 0.46 & 0.91 & 1.06 \\
\hline 2 & 0.59 & 0.53 & 0.99 & 1.05 \\
\hline 3 & 0.47 & 0.53 & 1.02 & 1.07 \\
\hline 4 & 0.36 & 0.31 & 1.03 & 0.98 \\
\hline 5 & 0.13 & 0.05 & 0.91 & 1.03 \\
\hline 6 & 0.24 & 0.31 & 0.93 & 1.15 \\
\hline 7 & 0.24 & 0.18 & $1: 03$ & 1.05 \\
\hline 8 & - & - & 1.00 & - \\
\hline
\end{tabular}

間隔 $100 \mathrm{~mm}$ を基準 として，上下染だ け，外側の縦枠だけ，および中通りの縦 枠だの釗間隔を変化させた各場合につ いて計算した。Fig. 12 はその結果を示 したもので,これから次の 2 点が看取さ れる。(1) 外側の縦枠（合板の 長い方の 緑をとめている枠)の釷間隔をつめた (広げた) 方が，上下枠（合板の短い方 の縁它とめている）のそれをつめた（広 げた）ときより影響が大きい。(2) 中通
は, 面材の種類や張り方によって異なっているが, 值の 高いものほど面材が有効に㗢いていると考えられる。逆 に，值の低いものは，釗接合部が面材の持てる抵抗力に 見合うだけの力を伝達していない事を示しているので, 釘接合の改良を行えば，壁剛性の上昇の余地があるかも しれない。

\section{5 数 值 実 験}

この項では，釗間隔が壁のせん断性能に与える影響を 数值実験飞よって調べた。

計算の対象とした壁は，上下㭠と等間隔に配置した 3 本の縦枠からなる枠組に, 1 枚の合板を張った, 寸法 $900 \times 2400 \mathrm{~mm}$ のもので, 釘接合部のせん断特性は, 試 験体 No. 1 のそれを使用し，また合板のせん断弹性係 数は $5000 \mathrm{~kg} / \mathrm{cm}^{2}$ とした。

ます，各枠材に打たれた釘の貢献度をみるために，釗
りの釷の貢献度は非常に小さい。

次に, 中通りの釷間隔は外周の釷間隔の 2 倍であると して，壁全体の釗間隔を変化させた場合について計算し た。Fig. 13 注の結果を示したものであるが，ある定のせん断歪み時の荷重につれてみると, 釘本数が倍に なっても，荷重は必ずしも倍にはならないことがわかる (図中の点線)。これは, せん断歪みrの中に占める面材 のせん断歪み $r_{S}$ の割合が，釘本数によって変わるから

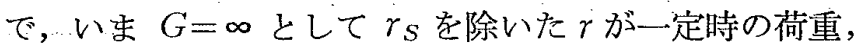
あるい㵊大荷重（図中の実線）についてみると, これ 等は釗本数に正比例することがわかる。

なお，この関係が，壁寸法や釗接合部のせん断特性に かかわりなく成立することは, 式 $(7)^{\prime},(8)^{\prime},(9)$, (11)'等から証明することが出来るが, 詳しい説明は省 略した。 


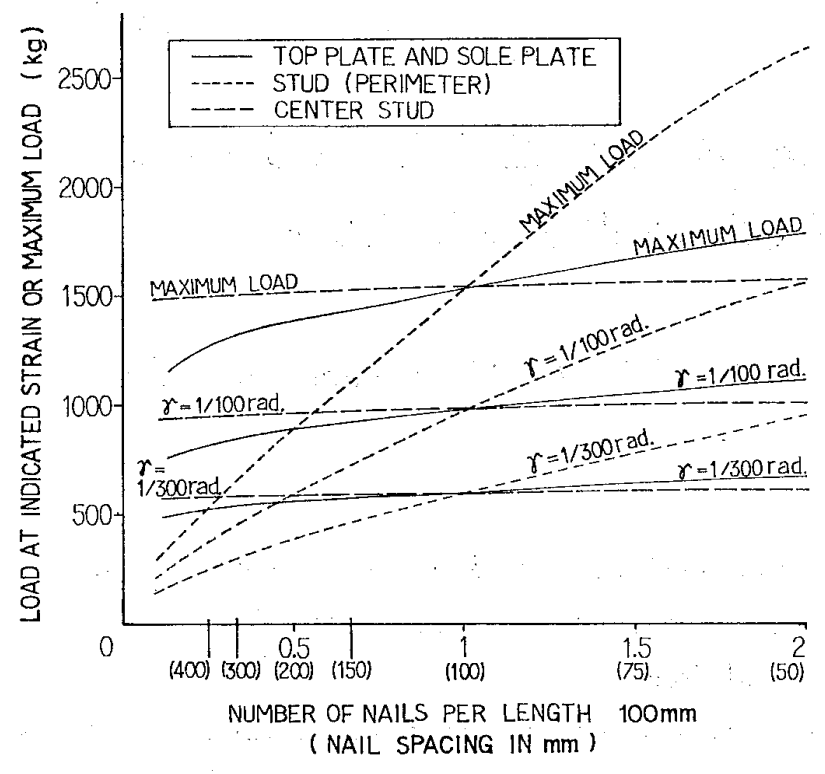

Fig. 12 Effect of the number of nails on each framing member under the condition in which the nail spacing on the other framing members is $100 \mathrm{~mm}$

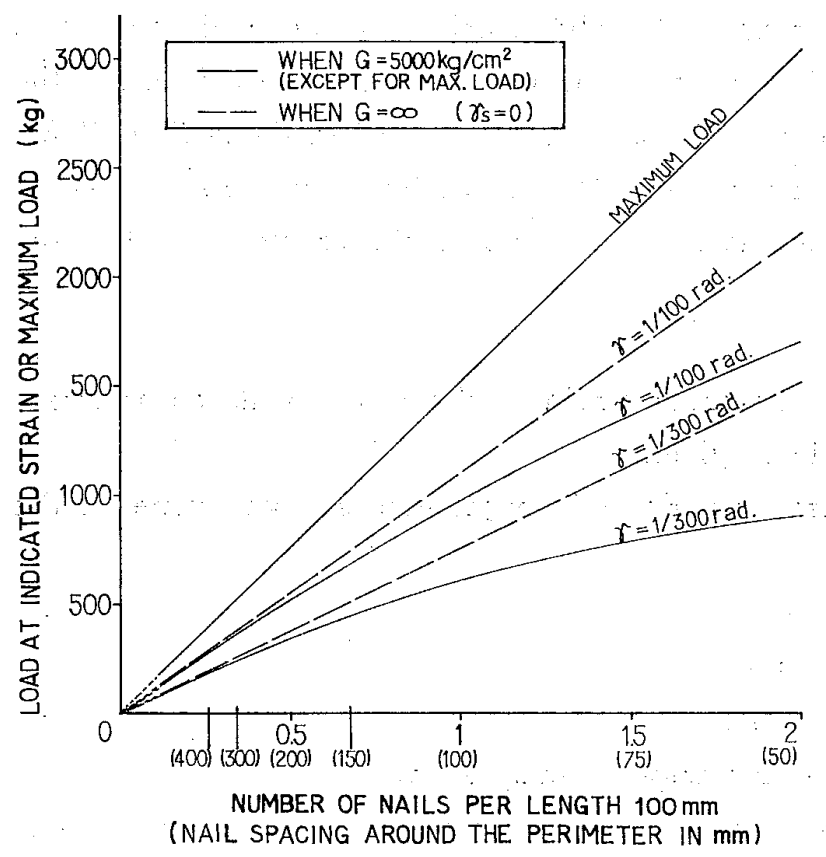

Fig. 13 Effect of the number of nails under the condition in which the nail spacing around the perimeter is half of that along the intermediate

\section{6 結論}

面材を釘打ちした耐力壁の，せん断性能を予測する理
論式を誘尊した。計算に必要なデータは, 壁の寸法, 面 材のせん断弹性係数，釷打ちパターン，および釷接合部 のせん断性能等である。

実験によりその適合性を検討した結果，壁のせん断歪 みと最大耐力については，非常に良く適合することが判 った。な拉，面材一枠材閒の之りについての適合性は， これよりやや劣るが，その原因は枠材の曲げ変形を考慮 しなかったためであると思われる。

理論式はやや複雑であるので，標準構成の壁に対象を 限定して近似式を求めた。近似式の計算はごく簡単で, 理論式とほとんど同じ解を与えるものである。

本研究と，種々の条件下に扝ける釗接合部のせん断性 能についての研究とを結びつけることにより，壁の施工 直後の短期的な強度性能だけでなく，時間ファクタが影 響する長期的視野での強度性能の推定が期待される。同 時に，本理論を発展させ，その対象範囲を更に拡張する ことを，今後共検討する必要があると思われる。

\section{謝 辞}

本研究にあたり，御指導と御協力を睗った当場の山井 良三郎氏，畑山䧧男氏，平嶋義彦氏ならびに金谷紀行氏 に対し，深甚なる謝意を表します。

\section{参，考 文 献}

1) Neisel, R.H., and Guerrera, J.F., "Racking Strength of Fiberboard Sheathing", TAPPI, Vol. 39, No. 9, Sept., 1956

2) Neisel, R.H., "Racking. Strength and Lateral Nail Resistance of Fiberboard Sheathing", TAPPI, Vol. 41, No. 12, Dec., 1958

3) Welsch, G:J., - "Racking Strength of Half-Inch Fiberboard Sheathing, "TAPPI, Vol. 46, No. 8, Aug., 1963

4）野口弘行，「有限要素法による木質パネルのせ儿断性状 (弾・塑性) の解析」, 「同その 2 」, 日本建築学会学術請 演梗概集 昭和 54 年 9 月, 昭和. 55 年 9 月

5) Tuomi, R.L., and MaCutcheon, W.J.," "Racking Strength of Light-Frame Nailed Walls", Journal of Structural Division, ASCE, Vol. 104, No. ST 7, July, 1978

6) 坂本 功「下地フレームと表面パネルからなる非耐力壁 の層間変位に対する挙動の解析」，「同その（2)」，日本建 築学会学術講演梗概集, 炤和 54 年 9 月, 昭和 55 年 9 月

7）平嶋義彦，畑山靖男，神谷文夫，金谷紀行「既存木造住 宅の耐震補強に関寸る研究 第 4 報」日本建築学会 学術 講演梗概集 昭和 55 年 9 月

8）後藤一雄「木構造の計算」鹿島出版会 昭和 55 年 4 月 


\title{
THEORETICAL STUDIES ON RACKING STIFFNESS AND STRENGTH OF WOODEN SHEATHED WALLS
}

\author{
by FUMIO KAMIYA*, Member of A.I.J.
}

\section{$\$ 1$ Introduction}

We have no established method for determining racking performance of wooden sheathed walls except for the laboratory full-size tests. Since this is a costly and time-consuming method, it is hardly possible to know the performance under many different conditions.

On the other hand, on the lateral nail resistance which seems to be the most important factor, many studies under various kinds of condition including long duration loading have been reported.

If an analytical procedure which predicts the performance is developed, we might predict not only the short-term performance but also the long-term performance using the results of these studies on nail.

\section{$\$ 2$ Previous works}

The methods for determining racking stiffness or strength of walls which have been developed in the previous works are devided into three types depending on their means, i.e., the method using the empirical equations (1, 2, 3), FEM (Finite Element Method) (4) and the theoretical methods $(5,6,7,8)$.

A theoretical equation has been reported by R.L., Tuomi and W.J., McCutcheon. But this equation is not applicable to stiffness computations. Because this is derived under the assumption that the load/distortion relation for a single nail is linear.

\section{$\$ 3$ Derivation of the theoretical equation}

The shear strain of wall, $r$ is computed by adding the shear strain of sheet, $r_{S}$ to the shear strain of wall frame, $r_{N}$ which is caused by nail slip; Eq. (1) is given.

The shear stress distribution in sheet is not uniform, but Eq. (2) might give a close value to the strain $r_{S}$.

$r_{N}$ was derived under the following assumptions

1... The joints of wall frame are assumed to be hinges.

2. Any deformation of studs and plates does not occur.

3. Nail pattern is symmetrical and wall frame is symmetrically constructed.

Consider a wall with a single sheet of sheathing and three studs. Denoting the corner nail distortion as $\delta_{c}$, the horizontal component and the vertical component of $\delta_{c}, u$ and $v$, each nail distortion and the components are obtained geometricaly (see Fig. 1).

Let the relation between the lateral load of a single nail, $q$ and the slip, $\delta$ be written as Eq. (3). In fact wood frame and some kind of sheet are anisotropic. Therefore the relation should correctly be written as a formula including the angles between the force directions and the fiber directions of materials.

Consideration about anisotropic character makes the subsequent equations very complex, therefore their materials have been assumed to be isotropic.

For nails on each plate and stud, the distortions, forces and their components are given as Eqs. (4), (5) and (6), in which subscripts $i, j$ and $k$ are contributions of nails on top (sole) plate, side stud and center stud respectively (see Fig. 2).

The horizontal component of nail force gives plus moment around the center point of sheet and the vertical component, negative moment. Denoting total moment of them as ${ }_{x} M$ and ${ }_{y} M$ respectively, ${ }_{x} M$

* Research Engr. Forestry and Forest Products Research Institute 
and ${ }_{y} M$ are given as Eqs. (7) and (8). Eq. (9) is the equation of the equilibrium. The $u / v$ relation is obtained solving Eqs. $\cdots(7)$, (8) and (9).

In order to solve them, the $q=f(\delta)$ curve which is obtained from the experiment must be approximated by a certain formula. It seems to be available to approximate it by the composition of connected straignt lines and solve them by the numerical solution. The computer program is so simple that a. programable electronic calculator is enough for the calculation.

$r_{N}$ is given as Eq. (10), in which $h$ is vertical distance between corner nails and $l$ is horizontal distance between corner nails.

As the internal energy absorved by nails is equal to the external energy, Eq. (11) is given. The simple Eq. (11)' gives the same result as Eq. (11).

The $P / r_{N}$ relation is obtained solving above.

If we define "nail force per unit length of framing member", Eqs. (7) and (8) can be rewritten as Eqs. (7)' and (8)' using integral symbol. These two equations are usefull when the effect of nail: spacing to the wall stiffness is investigated.

In case of the wall with multiple studs: Calculate the nail forces and distortions like Eqs. (4) to (6), and add their rotation moment to Eqs. (7) and (8).

In case of the wall with two seets: If their dimensions are equal, there is no problem. If their dimensions are different, it is difficult to predict the deformation accurately, because the movements of sheets are not equal and they interact to each other. Also the stiffness of stud produces important effect on the deformation of wall. But adding the results which are calculated about each part with a single sheet might give a similar solution.

Apploximate formula

When $f=(\delta)$ is linear, Eqs: (4) to (11) are easily solved as Eq. (12) in which $\alpha$ is slip modulus. Now, we put a limitation to the application as $h / l$ ratio $=2$ to $3, \delta_{c}$ (at the corner) is maximum in all nail displacements, $u$ (at the center of plate) is minimum and $v$ (at the center of side stud) is medium.

Substituting $f(v)$ for $\alpha v$ in Eq. (12), $\mathrm{Eq}(13)$ is obtained. This equation is the approximate formula. This substitution means that $\mathrm{q}=\alpha \delta$ is approximated by $q=f(\delta)$ in the interval $u \leqq \delta \leqq \delta c$ (see Fig. 3).

Fig. 4 shows that Eq. (13) gives a close solution to the theoretical result.

\section{$\$ 4$ Experiment}

Eight types of wall were tested to examine the validity of the theoretical solutions. The specimens are shown in Fig. 5 and Table 1. Testing method is shown in Fig. 6.

Improved Larsson-Wastlund Method was adopted to obtain the shear modulus of sheet, $G$. Lateral nail tests were conducted by the method as shown in Fig. 7.

Test results and discussions

Shear strain of sheet, $r_{S}:$ Fig. 8 shows load $-r_{S}$ characteristics. These relations are almost linear except No. 3. The values of $G$. which were obtained from two different tests-wall racking test and panel shear test-were shown in Table 2.

These two values of $G$ are almost equal except No. 5 (Insulation fiberboard).

Slip in the sheet-frame joint, $u$ and $v$ : Fig. 9 shows two typical examples of load-slip curve -comparatively better agreement and worse agreement.

Generally the observed value of $u$ has a tendency to be greater than the calculated value. This tendency may be due to the deflection of stud which caused by nail forces.

The deflection which was observed in the experiment was shown in Fig. 10. When the stud deformes like this, the horizontal force component of nail on stud reduces. Therefore $u$ must increase in order to satisfy Eq. (9).

Shear strain of wall, $r$ and strength : Fig. 11 shows load $r$ curves. The calculated results agree 
with the observed results.

Generally the observed strength was slightly lower than the calculated strength. This is expected as the end distance of nail is not taken into consideration in the lateral nail test.

It is general in Japan that the allowable strength of wall is estimated on the basis of the load at $r=1 / 300 \mathrm{rad}$. and the maximum load. The related data to this were shown in Table 3 . The value of $r_{S} / r$ indicates the contribution of sheathings to the wall stiffness.

\section{$\$ 5$ Numerical experiment}

The wall which is constructed with a single $900 \mathrm{~mm}$ by $2400 \mathrm{~mm}$ sheet of plywood, two plates and three studs was chosen as the subject to this experiment: The value of $G, 5000 \mathrm{~kg} / \mathrm{cm}^{2}$, was assigned and the same load-slip curve of nail for specimen No. 1 was used.

Fig. 12 shows the effect of the number of nails on each framing member under the condition in which the nail spacing on the other members is kept constantly $100 \mathrm{~mm}$ O.C. . From this figure it is seen that the contribution of the nails on top plate and sole plate is smaller than that of the nails on side studs. And it is also seen that the contribution of the nails on center stud is very small.

Fig. 13 shows the effect of the nails under the condition in which the nail spacing around the perimeter is half of that along the intermediate. Even if the number becomes doubled, the load corresponding to the same shear strain does not double. This is due to the change of the ratio $r_{N}$ to $r$. If $G=$ is $\left(r_{S}=0\right)$, the load is proportional to the number of nails, which can be proved from Eqs. (7)', (8), (9), (10) and (11)'.

\section{\$ 6 Conclusion}

An analytical procedure has been developped for calculating the racking stiffness and strength of sheathed walls.

The experiment has shown that the calculated result gives close agreement with experimental data.

An simple approximate. formula has been presented too. It gives almost equal solution to the theoretical result within the defined limit of wall composition. 